Global Conferences Series:

Social Sciences, Education and Humanities (GCSSSEH), Volume 2, 2019

The $2^{\text {nd }}$ International Conference on Sustainable Development \& Multi-Ethnic Society

DOI: https://doi.org/10.32698/GCS.01111

\title{
The Level of Global Competence among Students of Institut Pendidikan Guru Kampus Dato' Razali Ismail, Terengganu, Malaysia
}

\author{
Nurhijrah binti Zakaria ${ }^{1}$, Pajuzi bin Awang ${ }^{2}$, Badrul Muin binti Muhamad Adam ${ }^{3}$, \\ Hammadah bin Abdul Rahman ${ }^{4}$, Hj. Salleh bin Said ${ }^{5}$ \& Rashihah binti Hj. Muhammad \\ ${ }^{123456}$ Institut Pendidikan Guru Kampus Dato’ Razali Ismail, Kuala Nerus, Terengganu, MALAYSIA \\ E-mail: nurhijrah@ipgm.edu.my
}

\begin{abstract}
This study aimed to identify the level of global competence among students of the Institute of Teacher Education Dato' Razali Ismail Campus (IPGKDRI), Kuala Nerus, Terengganu. The study population consisted of 979 full-time students comprising PPISMP and PISMP students. A total of 274 respondents were selected using a randomized sampling method based on Krejcie and Morgan's table (1970). A data collection was done online using questionnaires built through Google Form. The data collected were screened through data purification, Alpha Cronbach's test, and Data Identification Test. The data were analyzed using the descriptive and inference statistics analysis. The findings showed that the level of global competence among IPGKDRI students was high in terms of global knowledge but moderate in the acceptance of cultural diversity. This study aims to raise awareness on the needs for global competencies in teacher education to ensure that they remain relevant as educators who can meet the challenges of 21 st-century educators.
\end{abstract}

Keywords: global competence, global issue, multicultural competence, global involvement, IPG students

\section{Introduction}

Global competency is the ability to examine local, global and multicultural issues in understanding perspectives, and the world-view of others in order to enable openness and effective interaction with people of different cultures, so that collective well-being and sustainable development are maintained (OECD 2018).

Global competency is needed for a more harmonious life in a multicultural community. It is necessary for the changes of the global job market, using productive and responsible media platforms and supporting sustainable development goals in all aspects, poverty, imbalance, climate, deterioration in environmental quality, well-being, harmony, and justice. Schools play an essential role in helping students to develop global competencies, providing opportunities for learning about global development such as engaging students in intercultural relations, and promoting cultural values.

The younger generation is seen as people who are actively involved in designing the environment for the future. 
Regardless of where they are born, lived, and worked. The world today needs them who are knowledgeable and interested in knowing more about their surroundings. Consequently, being confident, challenging, flexible, resilient, as well as mastering communication and social interaction skills are a must to meet a rapidly changing, interrelated, and interdependent world.

The 21st-century generation students live independence, diversity, and rapidly changing the world. Economics, digital, culture, demographics around the world surround the lives of young people and enhance the intercultural connection of their everyday life. Complex environments create opportunities and challenges for future generations. Today's generation does not only need to learn to engage in a world of interdependence, but also to appreciate cultural differences. Developing global competence takes a long time; therefore, education plays a crucial role in achieving this goal (Barrett et al., 2014; Mansilla and Jackson, 2011, Deardorff, 2009, UNESCO, 2013; 2014; 2016).

Moreover, schools play a vital role in helping youngsters to build global competency. They need to provide the students with an opportunity to learn about global development that is significant to their lives. Schools can also teach the students to think critically, act effectively, and responsibly use digital information and social media. Besides, they also need to improve cultural sensitivity, the value of respect by encouraging students to gain experiences in order to nurture and appreciate the diversity of people, languages, and cultures (Sinicrope, Norris and Watanabe, 2007). Schools are also a place that can motivate young people to understand global places, societies, and situations as well as enhance their ability to make judgments and actions.

\section{The Importance of Global Competency}

The need for global competence among young people is to foster cultural awareness and respectful interactions in an increasingly diverse society. By appreciating the differences in their communities (communities, regions, cities, neighborhoods, and schools), they can learn to live together as a global citizen (UNESCO, 2014). Education should be able to teach them about the responsibility of eradicating racial views and discrimination (Najeemah 2011).

Furthermore, global competence is also needed by the younger generation to cope with the changing labor market. Educating students to gain global competency can improve job marketability. Global competency requires students to have practical communication skills and appropriate behavior in a diverse group, and this is one of the key successes in many jobs and coupled with technology-use skills to facilitate global connectivity. According to the British Council (2013), employers are more interested in those who are adaptable and able to apply and transfer their skills and knowledge in a new context. The willingness to work in a connected world requires young people to understand the complex dynamics of globalization, openness to diverse backgrounds, trust in diverse groups, and to show respect for others.

Besides, the importance of global competency can motivate today's generation to use media platforms effectively and responsibly. Digital transformation has helped them to view the world through interactions and perceptions of others. Online networks, social media, and interactive technologies provide a variety of learning opportunities for young people. At the same time, digital life can result in the younger generation separated from the real world that affects itself and others (Zuckerman, 2013). In this context, nurturing students with global competency can help them to use the digital space appropriately, understand better the world they live in, and account for their views in the media.

Global competence is also needed in support of Sustainable Development goals; to educate the younger generation on global issues such as social, political, economic, and environmental issues. In Objective 4.7 Sustainable Development Agenda, by 2030, all students will gain the knowledge and skills required for sustainable development - sustainable living, human rights, gender equality, fostering harmony, global citizenship, and appreciating cultural diversity (UNESCO, 2016).

\section{Teacher Education in Malaysia}

Every school has high hopes to achieve national education goals. In Malaysia, educational goals are reflected in the National Philosophy of Education as follows:

Education in Malaysia is an ongoing effort to develop the potential of a holistic and integrated individual further to create intellectually, spiritually, emotionally, and physically-balanced people based on trust and obedience to God. This effort is made to produce Malaysians who are knowledgeable, skilled, virtuous, responsible, and capable of achieving personal well-being and contribute to the harmony and prosperity of their families, communities, and countries.

Based on the development of education in the global world, together with engaging and contributing to families, communities, and countries, students also need to collaborate internationally. New pedagogy for deep learning (NPDL) introduced in schools in Malaysia and the Institute of Teacher Education (IPG) is a 21st Century pedagogical approach that 
outlines six skills that students need to master. These skills are art, collaboration, communication, creativity, critical thinking, and citizenship (Fullan and Langworthy 2013). These skills are also needed to produce competent students globally. The need for education and life challenges in the era of the Industrial Revolution 4.0 in the 21 st century and the impact of globalization require skilled teachers in many aspects, including global competence.

The teachers also need to have global competencies in order to accommodate their students with it. In the teacher training programme, its goal is to produce teachers who are virtuous, progressive, and scientific, ready to uphold the aspirations of the nation as well as the cultural heritage of the nation, secure individual development and maintain a united, democratic, progressive and disciplined society. To achieve this goal, the Institute for Teacher Education sets a mission of producing competent and passionate educators through dynamic teacher development programs towards world-class school education.

Global competency among students requires to develop from a lower level. In this regard, the global competency of primary school teachers should also take into account. Moreover, as global competence is a new feature of the OECD, preliminary examinations need to be made for both in-service and pre-service teachers. Implementing global competencies among IPG students is essential because they will perform their duties in primary schools; thus, they need to monitor as well as examined at an early stage.

In the context of assessing the global competence of trainee teachers, the assessment by PISA is used to bring about a comprehensive perspective with an effort to create a learning environment that invites young people to understand the outside world, interact with others and take action on building a sustainable society. The main goals of the study are to support the decision to improve the curriculum, teaching, and the role of schools in cultural diversity in producing a competent world citizen.

\section{Literature review}

Global competence developed by the OECD (2018) has four dimensions namely knowledge, values, attitudes and skills. These four dimensions include four areas of competence, which are (i) examining local, global and international issues, (ii) understanding and appreciating others' views, (iii) engaging in aspects of openness, adaptability and crosscultural interaction and (iv) taking collective action against well-being and sustainable development as shown in Figure 1.

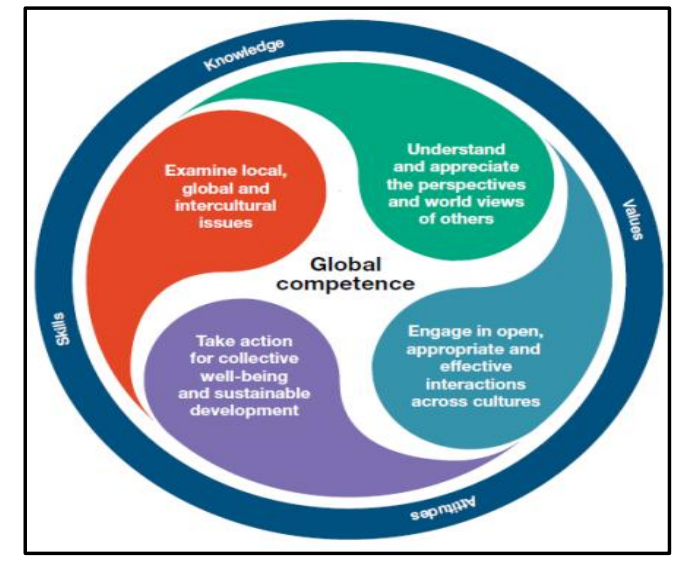

FIGURE 1: Dimensions of global competence

Source : The Organisation for Economic Co-operation and Development (OECD 2018)

Global competence developed by the OECD (2018) has four dimensions, namely knowledge, values, attitudes, and skills. These four dimensions include four areas of competence, which are (i) examining local, global and international issues, (ii) understanding and appreciating others' views, (iii) engaging in aspects of openness, adaptability, and cross-cultural interaction and (iv) taking collective action against well-being and sustainable development as shown in Figure 1.

This dimension refers to practical global competencies in the areas of global knowledge and critical reasoning as they shape their views on global issues. Students with global competencies can develop the necessary thinking models in schools such as questioning, data analysis, explaining phenomena, and developing an awareness of local and global issues (Boix Mansilla and Jackso 2011). The development of this dimension requires media literacy, such as the ability to access, analyze, and critically evaluate messages in the media to produce new messages (Buckingham 2007). In the context of education, global competency requires educators to understand local and global issues. The world's most pressing issues are poverty, immigration, globalization, technology, transportation, the movement of people across cultures, the absence of homogeneous countries, and the increasing cultural diversity of a country. Therefore, in the classroom, teachers need to teach using multicultural perspectives in order to understand the inclusion of the world population, especially concerning issues of justice (Roberts, 2007).

A study by Nurhijrah (2017) on the elements of multiculturalism in the teaching of history found that teachers need to be aware of and understand current issues both at home and abroad. This knowledge and understanding are vital to enable teachers to be prepared to explain to students 
or rationalize what is be raise. IPG students are also exposed to local and global issues through the Challenges, and Current Issues courses learned during the preparation course. In this course, students learn about current world political issues, world conflicts, the world economy, global issues, and their relation to the country and the challenges facing the country (Mohd Ashraf et al. 2017). Understanding these issues is intended to provide students with an opportunity to analyze the various issues and challenges in the world that gives impact to the country and the practical steps that can be taken to address the issue (GCI1022 Course Information Summary).

\subsection{Understand and appreciate the views of others}

Individuals with global competence can consider different perspectives of others from different points of view. To understand and appreciate others, one must know cultural history, values, communication styles, beliefs, and practices. They also believe that the behavior and perspectives of a different person are influenced by many factors that are different from others. This requires the person to examine his or her source and its implications to themselves, and others to understanding others will make one more empathic. Differing opinions is not an unhealthy one, but it can be beneficial as an issue can be viewed critically and allows for a solution to be resolved in the first place. In the context of different societies, different views must exist because they are born from different ideas. Maharom (2001) recognized that cultural experiences shape people's lives and thinking patterns. Nurhijrah (2017) also noted that understanding and appreciating differences in the views or culture of others is an element of competence that a teacher needs. This competency enhances effectiveness because multicultural skills allow teachers to improve their understanding of different cultural characteristics and assess the impact of their knowledge and beliefs in teaching students from different cultures (Spanierman et al. 2011). This competence among teachers is increasingly vital as a part of the delivery of the educational curriculum (Leighton 2009).

\subsection{Openness, ability to adapt and interact across cultures}

Global competence enables a person to interact with others from different cultures. They can understand cultural norms, flexible in their behavior, and also in communication. The ability to adapt and interact effectively allows them to understand others and be comprehended (Barrett et al., 2014). The capability to interact with people of different cultures makes one more flexible in thinking and behaving in order to accommodate the professional tasks and ways of working based on values, expectations, and guidance for working in a multicultural environment (Shwarzbaum \& Thomas 2008). Nurhijrah (2017) also found that in order to be culturally competent, a teacher needs to be open and able to accept people from different cultures with him. Also, multicultural competence can help one to adapt to a multicultural society and facilitate interaction with people of different languages and cultures. Global competencies can also help educators today to face the challenge of preparing students from diverse cultural backgrounds to live in an ever-changing society and world (Tarman \& Tarman 2011). Therefore, the willingness to accept, respect, and appreciate the differences existed is an important consideration that every citizen must practice. The advantage of teachers in the community, as they have experiences in a multicultural society, the teachers are more competent in managing multicultural students (Nurhijrah 2017).

\subsection{Executing collective action on well-being and sustainable development}

Global competence among students requires them to play a more active role as responsible members of society. This competence refers to an individual's willingness to respond and act on local, global, or cultural issues. A competent person highly has chances to gather information, reflective actions, and voices. The actions done by the person can be a statement of support, and he may take the initiative to create a campaign in the media or disseminating personal views. A person with global competence is continuously striving to improve the condition of his community in terms of harmony, inclusion, and environmental preservation.

Sustainable development is one to observe because the United Nations, through Resolution 57/254 in December 2002 recommended the Decade of Education for Sustainable Development 2005-2014 (DefSD) to UNESCO (UNESCO, 2007). This is a nationwide initiative in addressing environmental issues. Malaysia, as UNESCO's leading partner country, is also implementing Education for Sustainable Development (ESD) through environmentalbased informal education. Therefore, the teacher's response to this global issue is one of the forms of global competence.

Studies on the global competence of teachers can identify through several studies done both locally and internationally. Bordeianu (2019) did a survey involving 69 respondents from the teacher preparation program in the United States on global competencies for future educators in the areas of awareness, understanding, and behavior. The results showed that teacher training has a significant relationship with their global competence. Teachers who participate in global education programs have higher 
competencies than teachers who attend traditional preparation training.

The current world situation requires teachers to leverage their global knowledge and experience to enable them to transfer to students. Teachers also need to develop knowledge and skills to enable them to be relevant to other cultural experiences. A study conducted by Robert (2007) found that personal and professional experiences affect the global mindset. Overseas experience benefits trainees such as developing self-confidence, creating awareness of cultural diversity, and self-efficacy in dealing with multicultural people.

In Malaysia, studies of global competence among teacher students in teacher education institutes are still poorly studied. Researches on the elements of global competence can found in the 21st Century Education's study. However, these studies focus more on competencies in communication, collaboration, critical skills as well as creativity and innovation. IPG graduate teachers' competence studies that address 21st Century Education challenges in communication skills, collaboration, lifelong learning, information technology skills, and PdPc skills showed that they excellently obtain these skills (Nurhijrah et al. 2018). These excellent skills are among the factors that can contribute to global competitiveness. However, a study by Nurafiqah (2019) on the cross-curricular elements of the KSSR among trainee teachers found that trainees' knowledge of global sustainability is modest. A study by Hanifah Mahat et al. (2013) also found that awareness of sustainable development education by school students was at a moderate level.

Global competency assessment (PISA 2018) consists of two parts, namely, cognitive and background knowledge assessment. Cognitive assessment is designed to represent students' ability to respond to global issues, influence external perspectives and opinions, understand how to communicate with others in multicultural contexts as well as to identify and compare actions on global and intercultural issues. In a knowledge background survey, respondents asked about global issues, how they developed their linguistic and communication skills, their attitudes, and opportunities to develop global competencies. The concept of PISA 2018 global competencies and competent teachers for meaningful learning in the context of teacher education in the country needs to conceptualize through the global competency profile of IPG students. It can serve as a reference frame for the development of holistic educators in addressing the challenges and educational needs of the Industrial Revolution 4.0. In this regard, the research on the students' global competency level needs to be studied.

\section{Research objective and questions}

The objective of the study was to identify the global competency level of the Institute of Teacher Education Dato' Razali Ismail Campus (IPGKDRI) students based on demographic factors. Here are the research questions:

1. What is the level of global competency of IPGKDRI students?

2. Is there any differences between the degree of global competency of IPGKDRI students and demographic factors?

\section{Methodology}

This study uses a design study conducted on 970 students of IPG Dato' Razali Ismail Campus, Kuala Nerus, Terengganu, who are currently pursuing full-time studies of preparatory undergraduate students (PPISMP) and the Bachelor of Teaching (PISMP). The study sample consisted of 274 students selected through a random sampling method from a population of 880. Based on Krecjie and Morgan's (1970) Table. The respondents' background is, as shown in Table 1.

\begin{tabular}{|c|c|c|c|c|}
\hline No & & Variables & Respondents & $\begin{array}{l}\text { Percentage } \\
(\%)\end{array}$ \\
\hline 1 & Gender & $\begin{array}{l}\text { Male } \\
\text { Female }\end{array}$ & $\begin{array}{l}66 \\
134\end{array}$ & $\begin{array}{l}33.0 \% \\
67.0 \%\end{array}$ \\
\hline 2 & $\begin{array}{l}\text { Program } \\
\text { mes }\end{array}$ & $\begin{array}{l}\text { PPISMP } \\
\text { PISMP }\end{array}$ & $\begin{array}{l}102 \\
98\end{array}$ & $\begin{array}{l}51.0 \% \\
49.0 \%\end{array}$ \\
\hline 2 & $\begin{array}{l}\text { Intake } \\
\text { Cohort }\end{array}$ & $\begin{array}{l}\text { PPISMP } \\
\text { PISMP Sem } \\
7 \\
\text { PISMP Sem } \\
5 \\
\text { PISMP Sem } \\
3 \\
\text { PISMP Sem } \\
1\end{array}$ & $\begin{array}{l}102 \\
25 \\
39 \\
16 \\
18\end{array}$ & $\begin{array}{l}51.0 \% \\
12.5 \% \\
19.5 \% \\
8.0 \% \\
9.0 \%\end{array}$ \\
\hline 3 & $\begin{array}{l}\text { Program } \\
\text { mes } \\
\text { - }\end{array}$ & $\begin{array}{l}\text { Bahasa } \\
\text { Melayu } \\
\text { Bahasa } \\
\text { Inggeris } \\
\text { Pendidikan } \\
\text { Islam } \\
\text { Sains } \\
\text { Pendidikan } \\
\text { Seni Visual } \\
\text { Sejarah }\end{array}$ & $\begin{array}{l}38 \\
54 \\
63 \\
11 \\
25 \\
9\end{array}$ & $\begin{array}{l}19.0 \% \\
27.0 \% \\
31.5 \% \\
5.5 \% \\
12.5 \% \\
4.5 \%\end{array}$ \\
\hline
\end{tabular}

TABLE 1: Background of the respondents involved in the study

Based on Table 1, the total number of respondents which is 200 out of 974 full-time students are currently studying at PPISMP and PISMP. Respondents were selected using the stratified random sampling method based on the Krejcie and 
Morgan (1970) table. In terms of gender, female students $(67.0 \%)$ were more than men $(33.0 \%)$ while PPISMP students $(51.0 \%)$ and PISMP (49\%) were nearly equal. In terms of programs, Islamic Education students $(31.5 \%)$ were the most responsive students followed by English (27.0\%), Malay (19.0\%), Visual Arts Education (12.5\%), Science and History $(4.5 \%)$ students.

The instrument used is a questionnaire form built through Google form. It was translated from the PISA 2018 Global Competence Questionaire and adapted to the context of teacher education in Malaysia. The contexts tested in this study are i) Knowledge of global issues, ii) Attitudes towards cultural differences, iii) Acceptance of cultural diversity and iv) Collective action on well-being and sustainable development. The construct is based on dimensions of knowledge, attitudes, values and skills.

The data were analyzed using Statistical Package for the Social Sciences (SPSS) software, version 23 for descriptive and inference data. Prior to the statistical test, Alpha Cronbach's test was performed to obtain reliability item scores. Based on the tests performed, the Cronbach's Alpha scores ranged from 0.919 to 0.923 . The average Alpha Cronbach's alpha value is 0.921 as shown in Table 2 . According to Now (1992) Alpha Cronbach's alpha value above 0.06 is a value that reflects high reliability.

\begin{tabular}{|l|l|l|}
\hline $\begin{array}{l}\text { Cronbach' } \\
\text { s Alpha }\end{array}$ & $\begin{array}{c}\text { Cronbach's Alpha Based on } \\
\text { Standardized Items }\end{array}$ & N of Items \\
\hline .921 & .899 & 79 \\
\hline
\end{tabular}

TABLE 2: Alpha Cronbach's Test

Normalization tests were performed to obtain Skewness and Kurtosis values in order to determine whether the data were normally distributed. The data is normally distributed when Skewness and Kurtosis values are between -1 to +1 . In this test, the values of Skewness and Kurtosis results are as follows in Table 3:

\begin{tabular}{|l|c|c|c|}
\hline Construct & $\begin{array}{l}\text { Skewness } \\
\text { Value }\end{array}$ & $\begin{array}{l}\text { Kurtosis } \\
\text { Value }\end{array}$ & Interpretation \\
\hline $\begin{array}{l}\text { 1. Knowledge of } \\
\text { global issues }\end{array}$ & .472 & .231 & normal \\
\hline $\begin{array}{l}\text { 2.Processing value } \\
\text { against different } \\
\text { culture }\end{array}$ & -.126 & -.439 & normal \\
\hline $\begin{array}{l}\text { 3. Acceptance of } \\
\text { diversity }\end{array}$ & -.210 & -.121 & normal \\
\hline $\begin{array}{l}\text { 4. Collective action } \\
\text { towards } \\
\text { well-being and } \\
\text { sustainable } \\
\text { development. }\end{array}$ & .298 & -.503 & normal \\
\hline
\end{tabular}

TABLE 3: The Value of Skewness and the Value of Kurtosis

Since the data obtained were normally distributed, parametric tests were used to analyze the findings.

\subsection{Findings of Study 1: What Are the Competitive Levels of IPGKDRI Student Culture?}

The degree of global competency among IPGKDRI students is measured based on four key constructs which are i) Knowledge of global issues, ii) Perspective on cultural differences, iii) Acceptance of cultural diversity and iv) Collective action on well-being and sustainable development.

\subsubsection{Knowledge of global issues.}

The ability to examine local, global, and cultural issues is based on the self-efficacy of global issues ii) awareness of global issues and iii) global thinking. The results of the analysis are shown in Table 4,6.1.1.

\begin{tabular}{|c|c|c|c|c|c|}
\hline \multirow[b]{2}{*}{ Sub-construct } & \multirow{2}{*}{$\begin{array}{l}\mathrm{N} \\
\text { Statisti } \\
\mathrm{c}\end{array}$} & \multicolumn{2}{|l|}{ Mean } & \multirow{2}{*}{\begin{tabular}{|l|}
$\begin{array}{l}\text { Std. } \\
\text { Deviation }\end{array}$ \\
Statistic \\
\end{tabular}} & \multirow[b]{2}{*}{$\begin{array}{l}\text { Interpr } \\
\text { etation }\end{array}$} \\
\hline & & Statistic & $\begin{array}{l}\text { Std. } \\
\text { Error }\end{array}$ & & \\
\hline $\begin{array}{l}1 . \quad \text { Self- } \\
\text { efficacy on } \\
\text { issues, } \\
\text { global } \\
\text { issues }\end{array}$ & 200 & 2.842 & .035 & .488 & High \\
\hline $\begin{array}{l}2 . \\
\text { Awareness } \\
\text { on global } \\
\text { issues }\end{array}$ & 200 & 2.807 & .036 & .508 & High \\
\hline $\begin{array}{l}\text { 3. Global } \\
\text { thinking }\end{array}$ & 200 & 3.184 & .029 & .406 & High \\
\hline $\begin{array}{l}\text { Overall } \\
\text { Mean }\end{array}$ & 200 & 2.944 & .033 & .467 & High \\
\hline
\end{tabular}

TABLE 4, 6.1.1: Knowledge of global issues

According to Table 4a, the overall mean knowledge on global issues among IPGKDRI students is high $(2,944)$. The highest mean is for sub-constructs of global thinking (3.184), followed by self-efficacy on global issues (2.842) and awareness on global issues (2.807).

\subsubsection{Perspectives on cultural differences}

Constructing perspectives on cultural differences encompasses the ability to understand and appreciate the views of others as measured from their perspective, awareness of cross-cultural communication and respect for cultural differences. The results of the analysis are shown in Table 4,6.1.2.

\begin{tabular}{|l|l|l|l|l|}
\hline Sub Construct & $\mathrm{N}$ & Mean & Std. & Interpr \\
\hline
\end{tabular}




\begin{tabular}{|c|c|c|c|c|c|}
\hline & Statistic & Statistic & $\begin{array}{l}\text { Std. } \\
\text { Error }\end{array}$ & $\begin{array}{l}\text { Devi } \\
\text { ation } \\
\text { Stati } \\
\text { stic }\end{array}$ & etation \\
\hline $\begin{array}{l}\text { 1. Self- } \\
\text { perspective }\end{array}$ & 200 & 3.00 & $\begin{array}{c}.041 \\
0\end{array}$ & .581 & High \\
\hline $\begin{array}{l}\text { 2. Awareness on } \\
\text { cross-cultural } \\
\text { communication } \\
\text { skills }\end{array}$ & 200 & 3.24 & $\begin{array}{c}.028 \\
4\end{array}$ & .402 & High \\
\hline $\begin{array}{l}\text { 3. Respecting } \\
\text { cultural } \\
\text { differences }\end{array}$ & 200 & 3.34 & $\begin{array}{c}.044 \\
9\end{array}$ & .636 & High \\
\hline Overall Mean & 200 & 3.19 & $\begin{array}{c}.038 \\
3\end{array}$ & .540 & High \\
\hline
\end{tabular}

TABLE 4, 6.1.2: Perspectives on cultural differences

Based on Table 4, 6.1.2, the mean value of the cultural differences perceptions is high. The highest mean value is respecting cultural differences (3.34), followed by awareness of cross-cultural communication skills (3.24) and personal perspective which was 3.00 .

\subsubsection{Acceptance of cultural diversity}

Acceptance of cultural diversity is measured through the respondents' openness, ability to adapt and interact across cultures, which can be identified through adaptability, willingness to learn other cultures, attitudes toward immigrants and relationships with people from other countries. The findings of the study are tabulated in Table 4,6.1.3.

\begin{tabular}{|c|c|c|c|c|c|}
\hline \multirow{2}{*}{$\begin{array}{c}\text { Sub } \\
\text { Construct }\end{array}$} & \multirow{2}{*}{$\begin{array}{c}\mathrm{N} \\
\text { Statistic }\end{array}$} & \multicolumn{2}{|c|}{ Mean } & \multirow{2}{*}{\begin{tabular}{|c|} 
Std. \\
Deviation \\
Statistic
\end{tabular}} & \multirow{2}{*}{$\begin{array}{l}\text { Interp } \\
\text { retation }\end{array}$} \\
\hline & & Statistic & $\begin{array}{l}\text { Std. } \\
\text { Error }\end{array}$ & & \\
\hline $\begin{array}{c}\text { 1.Customi } \\
\text { ty }\end{array}$ & 200 & 2.6817 & .04404 & 62276 & $\begin{array}{l}\text { Mode } \\
\text { rate }\end{array}$ \\
\hline $\begin{array}{c}\text { 2.The } \\
\text { desire to } \\
\text { learn about } \\
\text { other } \\
\text { cultures }\end{array}$ & 200 & 3.0588 & .05127 & .72508 & High \\
\hline $\begin{array}{l}\text { 3. Respect } \\
\text { for } \\
\text { immigrants }\end{array}$ & 200 & 2.5337 & .03849 & .54432 & $\begin{array}{l}\text { Mode } \\
\text { rate }\end{array}$ \\
\hline $\begin{array}{l}\text { Overall } \\
\text { Mean }\end{array}$ & 200 & 2.4523 & .04010 & .56765 & $\begin{array}{l}\text { Mode } \\
\text { rate }\end{array}$ \\
\hline
\end{tabular}

TABLE 4, 6.1.3: Acceptance of cultural diversity

According to Table 4,6.1.3., the level of acceptance of cultural diversity is moderate (Mean $=2.45$ ). Only sub- constructs of desire to learn about other cultures is high $($ Mean $=3.06)$ while adaptability to other cultures $(\min =$ 2.68) and attitudes toward immigrants are moderate $(\mathrm{min}=$ 2.53).

\subsubsection{Executing collective action on well-being and} sustainable development

Collective actions on well-being and sustainable development are identified through student engagement in global issues, linguistic and communication skills (spoken languages, other languages learned) and global activities at institutions. The findings of the study are shown in Table 4,6.1.4., Table 4, 6.1.5., and Figure 2 and Figure 3.

\subsubsection{Students' engagement on global issues.}

Students' engagement on global issues is measured through 8 items as shown in Table 4,6.1.4 below.

\begin{tabular}{|c|c|c|c|c|c|}
\hline \multirow[t]{2}{*}{ No } & \multirow[t]{2}{*}{ Item } & \multicolumn{2}{|c|}{ Yes } & \multicolumn{2}{|c|}{ No } \\
\hline & & $\begin{array}{l}\text { frequ } \\
\text { ency }\end{array}$ & $(\%)$ & $\begin{array}{l}\text { frequ } \\
\text { ency }\end{array}$ & $(\%)$ \\
\hline 1 & $\begin{array}{l}\text { I reduce the amount } \\
\text { of energy used at } \\
\text { home to protect the } \\
\text { environment. }\end{array}$ & 185 & 92.5 & 15 & 9.5 \\
\hline 2 & $\begin{array}{l}\text { I choose eco- } \\
\text { friendly products } \\
\text { even though they } \\
\text { are quite expensive }\end{array}$ & 161 & 80.5 & 39 & 19.5 \\
\hline 3 & $\begin{array}{l}\text { I respond to social } \\
\text { or environmental } \\
\text { issues posted online }\end{array}$ & 136 & 68.0 & 64 & 32.0 \\
\hline 4 & $\begin{array}{l}\text { I make sure that I } \\
\text { keep up to date with } \\
\text { activity information } \\
\text { around the world via } \\
\text { social media } \\
\text { (Facebook or } \\
\text { Twitter etc.) }\end{array}$ & 175 & 87.5 & 25 & 12.5 \\
\hline 5 & $\begin{array}{l}\text { I boycott products } \\
\text { or companies of } \\
\text { political interest, } \\
\text { cause ethical } \\
\text { conflicts or harm the } \\
\text { environment }\end{array}$ & 175 & 87.5 & 25 & 12.5 \\
\hline 6 & $\begin{array}{l}\text { I participate in } \\
\text { activities } \\
\text { promote that } \\
\text { between men and } \\
\text { women }\end{array}$ & 63 & 31.5 & 137 & 69.5 \\
\hline 7 & $\begin{array}{ll}\text { I participate in } \\
\text { activities related to } \\
\text { environmental }\end{array}$ & 173 & 86.5 & 27 & 13.5 \\
\hline
\end{tabular}




\section{RedWhitepress}

\begin{tabular}{|c|c|c|c|c|c|}
\hline & preservation & & & & \\
\hline 8 & $\begin{array}{lr}\text { I regularly read } \\
\text { websites } & \text { on } \\
\text { international social } \\
\text { issues (examples: } \\
\text { poverty, human } \\
\text { rights) }\end{array}$ & 158 & 79.0 & 42 & 21.0 \\
\hline
\end{tabular}

TABLE 4, 6.1.4: Students' engagement on global issues

Based on Table 4,6.1.4, all respondents rate 'yes' higher than 'no' responses except for item 6: I participated in activities that promote equality between men and women. This item receives a 'yes' response of $31.5 \%$ and a 'no' of $69.5 \%$. The

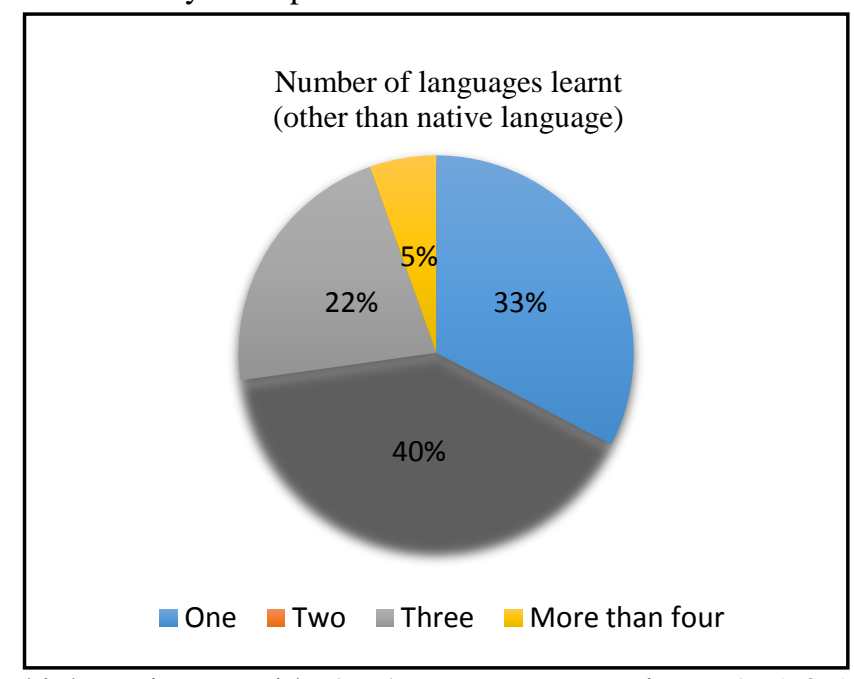

highest items with 'yes' responses are item 1 (92.5\%) followed by items 4 and $5(87.5 \%)$, item $7(86.5 \%)$, item 2 $(80.5 \%)$, item $8(79.0 \%)$ and item $3(68 \%)$.

\subsubsection{Communicating with other people}

\begin{tabular}{|l|l|l|l|l|l|}
\hline Bil & Item & Yes & No & \\
\cline { 3 - 6 } & & frequency & $(\%)$ & frequency & $(\%)$ \\
\hline $\mathbf{1}$ & $\begin{array}{l}\text { Among } \\
\text { family } \\
\text { members }\end{array}$ & 73 & 36.5 & 127 & 63.5 \\
\hline $\mathbf{2}$ & $\begin{array}{l}\text { At place of } \\
\text { study }\end{array}$ & 88 & 44.0 & 112 & 56.0 \\
\hline $\mathbf{3}$ & $\begin{array}{l}\text { In } \\
\text { neighbourh } \\
\text { ood }\end{array}$ & 85 & 42.5 & 115 & 57.5 \\
\hline $\mathbf{4}$ & $\begin{array}{l}\text { Among } \\
\text { friends }\end{array}$ & 126 & 63.0 & 74 & 37.0 \\
\hline
\end{tabular}

TABLE 4, 6.1.5: Communicating with people from other countries

Based on Table 4,6.1.5, respondents are found to be communicating with people in other countries. $36.5 \%$ communicate with family members living in another country. $44.0 \%$ are communicating with people from other countries where they were studying, $42.5 \%$ are communicating with those in the neighbourhood and some respondents communicating with their friends in other countries (63.0\%).

\subsubsection{Linguistic skills (the use of multiple languages)}

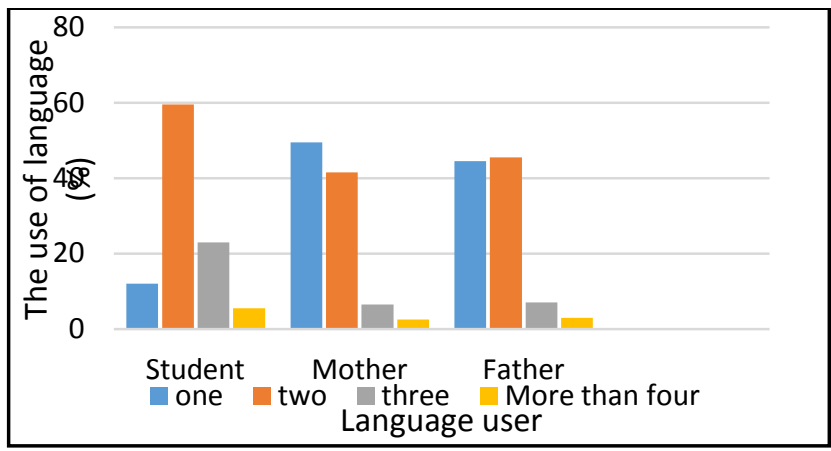

FIGURE 2: Number of languages used

In Figure 2, most respondents are found to use two languages as spoken languages. $12.0 \%$ of students use one language only, $59.5 \%$ of students speak two languages, $23.0 \%$ use 3 languages and $5.5 \%$ speak more than four languages. For parents, most of them use one language at home. Mothers are more likely to use one language (49.5\%; Fathers $44.5 \%$ ). The mothers who speak both languages were $41.5 \%$ and fathers are $45.5 \%$. Only a few parents use three or four languages and more.

\subsubsection{Linguistic skills (Learning another language other than native language)}

FIGURE 3: Number of languages learnt (other than native language)

Based on Figure 3, it is found that respondents are learning languages other than their native language. $23.0 \%$ learn only one language, $57.0 \%$ learn two languages, $16 \%$ learn 3 languages and some learn four languages.

\subsubsection{Students' engagement in global-related activities in institutions.}

Student engagement in global-related activities in institutions is measured based on 10 items shown in Table 4,6.1.6.

\begin{tabular}{|l|l|l|l|l|l|}
\hline No & Item & \multicolumn{2}{|l|}{ Yes } & \multicolumn{2}{l|}{ No } \\
\cline { 3 - 6 } & $\begin{array}{l}\text { frequen } \\
\text { cy }\end{array}$ & $\%$ & $\begin{array}{l}\text { frequen } \\
\text { cy }\end{array}$ & $\%$ \\
\hline 1 & $\begin{array}{l}\text { I learn about the } \\
\text { economic } \\
\text { relationship between } \\
\text { other countries }\end{array}$ & 176 & 88.0 & 24 & 12.0 \\
\hline 2 & $\begin{array}{l}\text { I learn to solve } \\
\text { problems between } \\
\text { my classmates }\end{array}$ & 193 & 96.5 & 7 & 3.5 \\
\hline 3 & $\begin{array}{l}\text { I learn about different } \\
\text { cultures }\end{array}$ & 191 & 95.5 & 9 & 4.5 \\
\hline
\end{tabular}




\begin{tabular}{|c|c|c|c|c|c|}
\hline 4 & $\begin{array}{l}\text { I read newspapers } \\
\text { and surf the Internet } \\
\text { to find the world } \\
\text { news }\end{array}$ & 190 & 95.0 & 10 & 5.0 \\
\hline 5 & $\begin{array}{l}\text { I always have been } \\
\text { asked by lecturers to } \\
\text { give views on } \\
\text { international news }\end{array}$ & 140 & 70.0 & 60 & 30.0 \\
\hline 6 & $\begin{array}{l}\text { I celebrate various } \\
\text { cultural events or } \\
\text { activities. }\end{array}$ & 159 & 79.5 & 41 & 20.5 \\
\hline 7 & $\begin{array}{l}\text { I regularly participate } \\
\text { in class discussions } \\
\text { on events happening } \\
\text { around the world. }\end{array}$ & 157 & 78.5 & 43 & 21.5 \\
\hline 8 & $\begin{array}{l}\text { I analyze global } \\
\text { issues with my } \\
\text { classmates in a small } \\
\text { group. }\end{array}$ & 164 & 82.0 & 36 & 18.0 \\
\hline 9 & $\begin{array}{l}\text { I learn that people of } \\
\text { different cultures } \\
\text { have different } \\
\text { perspectives on some } \\
\text { issues. }\end{array}$ & 196 & 98.0 & 4 & 2.0 \\
\hline 10 & $\begin{array}{l}\text { I learn how to } \\
\text { communicate with } \\
\text { people of different } \\
\text { cultures. } \\
\text { Average }\end{array}$ & 184 & $\begin{array}{l}92.8 \\
0 \\
87.5\end{array}$ & 16 & $\begin{array}{l}8.0 \\
12.5\end{array}$ \\
\hline
\end{tabular}

TABLE 4,6.1.6: Students' involvement in global activity practices in institutions.

In Table 4,6.1.6, the highest item of 'yes' response is item 9 $(98.0 \%)$ which is "I learn that people of different cultures have different perspectives on some issues" followed by item $2(96.5 \%)$, item $3(95.5 \%)$ ), item $4(95.0 \%)$, item 10 $(92.8 \%)$. Other items with less than $90 \%$ response are item 1 $(88.0 \%)$, item $8(82 \%)$, item $6(79.5 \%)$, item $7(78.5 \%)$ and the lowest item $5(70.0 \%)$, which is "I always have been asked by lecturers to give views on international news".

\subsection{Findings of Study 2: Is there any differences in the} level of global competency of IPGKDRI students based on demographic factors (Gender, Program and Student Options)?

\begin{tabular}{|l|l|l|l|l|l|l|l|}
\hline $\begin{array}{l}\text { Demogr } \\
\text { aphy }\end{array}$ & $\begin{array}{l}\text { Fact } \\
\text { or }\end{array}$ & $\mathrm{N}$ & Mean & SP & dk & $\mathrm{t}$ & Sig. \\
\hline \multirow{4}{*}{ Gender } & $\begin{array}{l}\text { Mal } \\
\mathrm{e}\end{array}$ & 66 & 3.02 & .360 & 198 & 0.895 & .036 \\
\cline { 2 - 8 } & $\begin{array}{l}\text { Fem } \\
\text { ale }\end{array}$ & 134 & 2.91 & .373 & & & \\
\hline \multirow{4}{*}{$\begin{array}{l}\text { Program } \\
\text { mes }\end{array}$} & $\begin{array}{l}\text { PPI } \\
\text { SM } \\
\text { P }\end{array}$ & 102 & 2.83 & .309 & 198 & - & .000 \\
\cline { 2 - 8 } & $\begin{array}{l}\text { PIS } \\
\text { MP }\end{array}$ & 98 & 3.06 & .397 & & & \\
\hline
\end{tabular}

TABLE 5, 6.2.1: Differences in the level of global competency of IPGKDRI students based on gender and faculty programmes.

Based on Table 5, 6.2.2, the t-values for the global competency level of IPGKDRI students are found to be $\mathrm{t}=$ 0.895 and the significance level is $p=0.036$. This significance level is smaller than 0.05 ( $\mathrm{p}<0.05)$. The null hypothesis is therefore rejected. It means that there are significant differences between male and female students. The mean score for the global male competency level is $($ mean $=3.02)$ greater than the female student $($ mean $=2.91)$. This proves that the global competency level of male students is better than that of female students.

Besides, there is a significant difference in the level of global competence $(\mathrm{t}=-4.614 ; \mathrm{p}<0.05)$ between students participating in the PPISMP and PISMP programs. Student competency level of the PPISMP program (mean $=2.83$ ) is lower than the global competency level of PISMP students (mean $=3.06$ ).

\begin{tabular}{|c|c|c|c|c|c|c|c|}
\hline $\begin{array}{l}\text { Demograp } \\
\text { hy }\end{array}$ & Factor & $\mathrm{N}$ & Mean & SP & $\begin{array}{l}\mathrm{d} \\
\mathrm{k}\end{array}$ & $\mathrm{t}$ & Sig \\
\hline \multirow{7}{*}{ Options } & $\begin{array}{l}\text { Bahasa } \\
\text { Melayu }\end{array}$ & 38 & $\begin{array}{l}2.893 \\
8\end{array}$ & $\begin{array}{l}.3460 \\
1\end{array}$ & 5 & $\begin{array}{l}4.96 \\
7\end{array}$ & $\begin{array}{l}.00 \\
0\end{array}$ \\
\hline & $\begin{array}{l}\text { Bahasa } \\
\text { Inggeris }\end{array}$ & 54 & $\begin{array}{l}3.066 \\
8 \\
\end{array}$ & $\begin{array}{l}.3464 \\
6 \\
\end{array}$ & & & \\
\hline & $\begin{array}{l}\text { Pendidik } \\
\text { an Islam }\end{array}$ & 63 & $\begin{array}{l}2.923 \\
8 \\
\end{array}$ & $\begin{array}{l}.4010 \\
2\end{array}$ & & & \\
\hline & Sains & 11 & $\begin{array}{l}2.957 \\
1 \\
\end{array}$ & $\begin{array}{l}.2110 \\
6 \\
\end{array}$ & & & \\
\hline & $\begin{array}{l}\text { Pendidik } \\
\text { an Seni } \\
\text { Visual }\end{array}$ & 25 & $\begin{array}{l}2.701 \\
5\end{array}$ & $\begin{array}{l}.3360 \\
2\end{array}$ & & & \\
\hline & Sejarah & 9 & $\begin{array}{l}3.227 \\
7\end{array}$ & $\begin{array}{l}.2624 \\
1\end{array}$ & & & \\
\hline & $\begin{array}{l}\text { Overa } \\
\text { 11 Mean }\end{array}$ & $00^{2}$ & $\begin{array}{r}2 . \\
9444\end{array}$ & $\begin{array}{r}.3 \\
7242 \\
\end{array}$ & & & \\
\hline
\end{tabular}

TABLE 5, 6.2.2: Differences in the level of global competency of IPGKDRI students based on the Option factors

In Table 5, 6.2.2, there is a significant difference in the level of global competence $(t=-4.967$; $p<0.05)$ between student options. It means that the null hypothesis is accepted. Student competency levels by option are Malay (mean = 2.893, English $($ mean $=3.067)$, Islamic Education $($ mean $=$ $2.92)$, Science $($ mean $=2.96)$, Visual Arts Education $($ mean $=$ 2.701 ), History (mean $=3.223$ Findings show that there is a significant difference between the level of student competence and student options.

\section{Discussion}

The degree of global competency among IPGKDRI students is measured based on four key constructs which are (i) 
Knowledge of global issues, (ii) Perspective on cultural differences, (iii) Acceptance of cultural diversity and (iv) Collective action on well-being and sustainable development. It is influenced by factors in learning in IPG, experience, living environment, adult influence, social media and the internet.

Knowledge of global issues among students of IPGKDRI is high. Their awareness of local and global issues influences global thinking among students. They are exposed to global issues as they participate in the PPISMP and the GCI1022 World Challenges and Current Issues course. However, the students' comprehension of them also depends on the pedagogical content knowledge of teachers, activities, assignments, opportunities, and students' attitudes towards learning the course itself. Zahari (2006) points out that the teaching and learning (R\&D) process that focused on students' knowledge and intellectual development depends on the professional knowledge of educators. Lectures and assignments for the Current Challenges and Issues course encourage students to explore global issues whether through the internet or in newspapers, discussions, or references in the library. According to Mohd Fuad et al. (2016) the internet is one of the essential sources for information on current issues.

Perspectives on cultural differences are high. Students are already exposed to the experience of living with friends from different cultures. The multiracial Malaysian society gives students a positive perspective on cultural diversity. Besides, students have an awareness of respect for differences, cross-cultural communication skills, and a personal perspective on global issues. The multicultural world causes individuals of different cultures to have their perspectives on cultural diversity and issues. Perspectives on other cultural values are also affected by the experiences of individuals or others with those cultures that create perceptions and views of different cultures. The level of global competence is also influenced by experience and a study by Cushner and Mahon (2016) found that trainee teachers who were experiencing with abroad environment and surroundings have a better international understanding. The most significant impact is on their self-confidence and also on other people based on cultural awareness, selfefficacy, self-awareness as well as professional improvement from the global mindset. This gives impacts on the acceptance of cultural diversity from cross-cultural awareness of a global perspective.

The level of acceptance of cultural diversity is at a moderate level. Only sub-constructs of desire to learn other cultures are high. The desire to learn about other cultures is influenced by the multi-ethnic and multi-cultural environment and in line with Nurhijrah's (2017) study, which suggests that in order to be competent in various cultures, teachers need to know and understand the culture of the local community. Flexible attitudes, tolerance and empathy for cultural diversity can also help one to adapt to society. On the other hand, at a moderate level, the adaptability and attitude towards immigrants. In this study, the level of adaptability was based on attitude when dealing with different situations and people of different cultures. This condition is influenced by psychological factors when someone can feel comfortable being in the same cultural group. It means that students are unable to adapt to other cultures when faced with circumstances. They also show a moderate attitude towards immigrants because most of them disagree on giving the right to vote in elections and get equal rights as citizens. Students know and understand that the right to vote is only granted to Malaysian citizens, which enshrined in the Malaysian Constitution.

Collective actions on well-being and sustainable development are identified through student engagement in global issues, linguistic skills and communication as well as global-related activities in IPG. The findings show that students are involved in global issues such as the environment and society. The application of environmental and social issues in education is one of the elements in the Sustainable Development Education recommended by UNESCO (2007). Students' ESD awareness is also influenced by educators and parents that have a profound impact on students and the environment outside of school settings (Norhanifah et al. 2013). Although involvement in global issues is high, students are less responsive to such issues online such as social media and blogs.

Additionally, students are more comfortable reading them as a silent reader than commenting. They are also more careful in making public comments, especially negative comments, as they will be distorted and affect the name of the commenter. Besides, linguistic skills are one of the elements of global competence. The findings prove that over 80 percent of students use more than one language. The use of different languages among them happens as a result of ethnic development in the country and language learning in the country's education system. In Malaysia, the primary language spoken by most Malaysians is Malay because it is the national language of the country.

Additionally, native languages such as Chinese, Tamil, English, Arabic and other languages, as well as foreign languages, are also used by the Malaysian community. Malay is the medium of instruction in educational institutions in the country (Education Act 1996). In IPG, besides learning Malay, students also learn English and Arabic languages depending on their options. In addressing 21st Century educational challenges and global education needs, students are encouraged to learn more than two languages to be more competitive internationally (PPPM 2013-2015). Future teachers must prepare for the challenges of global education to meet the current and upcoming education needs, that require the students to develop character development, communication, collaboration, 


\section{RedWhitepress}

Global Conferences Series: Social Sciences, Education and Humanities (GCSSSEH), Volume 2, 2019

creativity, critical skills and citizenship through meaningful learning.

\section{Implications of the Research}

This study gives impacts to improve the training of the IPG in both curriculum and programme, so that it achieves the goal of sustainable development education for international peace, harmony and sustainability. The improvements in curriculum and teacher training programs are believed to produce globally competent and capable teachers for the benefit and progress of global education. Global competency studies can also provide the impression that the education system needs to be integrated globally from a variety of perspectives in curriculum and classroom activities. Global competence is essential for pre-service teachers to gain cross-cultural experience to enable them to teach, work with people of different cultures.

\section{Summary}

The emphasis on global competency among students shows that future teachers who are being trained must also be given knowledge and skills in global activities. The global competence enables future teachers to build networks and collaborate with people from diverse backgrounds internationally and it is a significant factor in the mastery of 21 st-century learning skills. The global competence reflected in these dimensions of knowledge, attitudes, values and skills can provide an examination of current levels of competence. The significant global competence provides an opportunity for the improvement of the country's education system in line with global educational development.

\section{References}

[1]Akta Pendidikan 1996.

[2]Amy Roberts(2007).Global Dimensions of Schooling: Implications for Internationalizing Teacher Education. Teacher Education Quarterly. 9-26.

[3]Barrett, M., M. Byram, I. Lázár, P. Mompoint-Gaillard and S. Philippou (2014), Developing Intercultural Competence through Education, Council of Europe Publishing, Strasbourg

[4]Bordeianu.A.D(2019). Exploring global competencies for future educators: investigating students' global competency level in teacher preparation programs traditional versus global education. Ijazah Doktor Falsafah. Oakland University Rochester, Michigan.

[5]Buckingham, D. (2007), "Digital Media Literacies: rethinking media education in the age of the Internet", Research in Comparative and International Education, Vol.2/1, pp.43-55
[6]Cushner, K(2007). Internationalizing Schools and Colleges of Education: Educating Teachers for Global Awareness.Teacher Education Quarterly. 34(1) : 27-39.

[7]Cushner,K(2007).The Role of Experience in the Making of Internationally-Minded Teachers. Teacher Education Quarterly, 27-39.

[8]Deardorff, D. K. (2009), "Implementing Intercultural Competence Assessment" in The SAGE Handbook of Intercultural Competence, D. K. Deardorff (ed.), Sage, Thousand Oaks, CA, pp. 477-491.

[9]Hanifah Mahat, Mohamad Suhaily Yusri Che Ngah dan Shaharudin Idrus(2013).Kesedaran Pendidikan Pembangunan Lestari menerusi Program Sekolah Lestari dalam Kalangan Pelajar Sekolah di Malaysia. Geografi $1: 2,46-60$.

[10]Internationalizing Schools and Colleges of Education: Educating Teachers for Global Awareness. Teacher Education Quarterly.34(1):9-26.

[11]Kenneth Cushner and Jennifer Mahon(2002). Overseas Student Teaching: Affecting Personal, Professional, and Global Competencies in an Age of Globalization Overseas Student Teaching: Affecting Personal, Professional, and Global Competencies in an Age of Globalization. Retreave from https://doi.org/10.1177/1028315302006001004.

[12]Leighton.L. 2009. Teachers perception of their cultural competencies: An investigation in the relationship among teacher charactersistic and cultural competence. Thesis master, Mount Saint Vincent University.

[13]Mansilla, V. and A. Jackson (2011), Educating for Global Competence: Preparing Our Youth to Engage the World, Asia Society.Council of Chief State School Officers.

[14]Fullan,M dan Langworthy,M(2013).Towards a New End: New Pedagogies for Deep Learning. Collaborative Impact Seattle, Washington, USA.

[15]Maharom Mahmood, 2001, Towards a History Curriculum Description Nurturing patriotism among students. National Conference on Education History to the formation of patriotic citizens, 8 to 12 October. Kuala Lumpur.

[16]Mohd Ashraf Ibrahim, Mohd Aris Othman, Chin Kuang Tiu, Norazlan Ismail, Siti Fatihah Abdullah(2019). Cabaran dan isu semasa dunia. Petaling Jaya: Sasbadi Sdn. Bhd.

[17]Mohd Fuad Mat Jali, and Junaidi Awang Besar, and Rosmadi Fauzi, and Amer Saifude Ghazali, and Novel Lyndon, (2012) Akses kepada internet dan kesannya terhadap partisipasi politik penduduk di Negeri Johor. Geografia : Malaysian Journal of Society and Space, 8 (6). pp. 76-89. ISSN 2180-2491

[18]Nur Afiqah Ezani(2019). Hubungan pengetahuan elemen merentas budaya dengan pengintegrasiannya dalam 
pengajaran dan pembelajaran Sejarah. Tesis Sarjana Muda Perguruan. IPGKDRI.

[19]Nurhijrah Zakaria(2017). Elemen Kompetensi Pelbagai Budaya dalam pengajaran dan pembelajaran bagi guru Sejarah. Tesis Doktor Falsafah. Universiti Kebangsaan Malaysia.

[20]Nurhijrah Zakaria, Marzuki Ngah, Yuslaini Yunus, Fouziah Mohd, Kamarauzaman Zakaria.(2018). Kompetensi Guru Novis Keluaran Institut Pendidikan Guru Mendepani Cabaran Pendidikan Abad 21 Jurnal Penyelidikan Pendidikan IPGKTI.

[21]OECD (2016), PISA 2018 draft reading framework, OECD working paper, OECD, Paris.

[22]OECD (2018). OECD (2018). Preparing Our Youth for an Inclusive and Sustainable World: The OECD PISA Global Competence Framework. OECD, http://www.oecd.org/pisa/Handbook-PISA-2018-GlobalCompetence.pdf

[23]Ringkasan Maklumat Kursus GCI 1022. Cabaran dan isu semasa dunia. Edisi kemas kini 2017.

[24]Reyes L. dan Cordeiro, P.A(2007). Internationalizing Schools and Colleges of Education-Educating Teachers for Global Awareness. Teacher Education Quarterly. 34(1): 3-7

[25]Shwarzbaum, S.E. \& Thomas, A.J. 2008. Dimensions of Multicultural Counseling. New York : Sage Publications.

[26]Sinicrope, C., J. M. Norris and Y. Watanabe (2007), "Understanding and assessing intercultural competence: A summary of theory, research, and practice”, Technical report for the Foreign Language Program Evaluation Project, Honolulu, HI.

[27]Spanierman,L.B, Oh, E., Heppner, P.P, Neville,H.A., Mobley, M., Wright, C.V., Dillon,F.R. \& Navarro,R. 2011. The Multicultural Teaching Competency Scale : Development and Initial Validation. Urban Education. 46(3) 440-464

[28]Tarman, B. \& Tarman, İ. 2011. Teachers' Involvement in Children's Play and Social Interaction. Elementary Education Online 10(1): 325-337.

[29]UNESCO (2013), Intercultural Competences: Conceptual and Operational Framework, UNESCO, Paris.

[30]UNESCO (2014), Global Citizenship Education: Preparing learners for the challenges of the 21 st century, UNESCO, Paris.

[31]UNESCO (2016), Global Education Monitoring Report, UNESCO, Paris

[32]Yasmin Ahmad(2014). Sensitiviti dan kompetensi kepelbagaian budaya dalam kalangan guru pelbagai etnik di Malaysia. Tesis PhD. Universiti Sains Malaysia.

[33]Yuen, C.Y.M,(2010). Dimensions of diversity: Challenges to secondary school teachers with implications for intercultural teacher education. Teaching and Teacher Education.26(3):732-741.
[34]Zahari Ishak(2006). Psikologi Pendidikan: Realiti pengajaran dan Pembelajaran .Masalah Pendidikan. 2136 